\title{
External Metabolic Balance Studies During Nasogastric Feeding in Serious Illnesses Requiring Intensive Care
}

\author{
M. J. T. PEASTON,* M.B., M.R.C.P.GLASG.
}

Brit. med. F., 1966, 2, 1367-1368

The importance of nasogastric feeding in serious illness was first appreciated by John Hunter in 1776, and in 1790 he achieved complete nasogastric alimentation for 18 days in a man with paralytic dysphagia (Hunter, 1837). A tube feed of milk powder (Complan) and lactose was recently described which maintained metabolic balance in patients with a variety of serious illnesses in an intensive-care unit (Jones and Sechiari, 1963). In patients with respiratory failure requiring intermittent positive-pressure ventilation (I.P.P.V.) that diet was complicated by an incidence of diarrhoea approaching $20 \%$ (Jones and Peaston, 1966). This paper describes a modified tube feed in which external metabolic balance data confirmed its capacity to maintain metabolic balance and with which diarrhoea was less frequent.

\section{Methods and Materials}

Seven control subjects were fed on the Complan-lactose diet (diet A) for five days while continuing their normal lives, and external metabolic balance data were compiled for water, sodium, potassium, chloride, and nitrogen. Similar data were obtained from seven further controls on the modified diet (diet B), and subsequently in 20 patients admitted to an intensive-care unit with serious illnesses.

TABLB I.-Corrections per Day for Insensible Losses from Lungs, Skin,

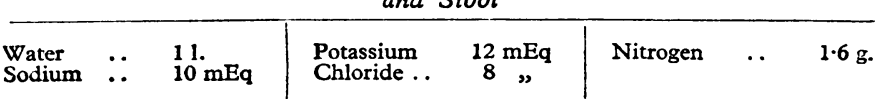

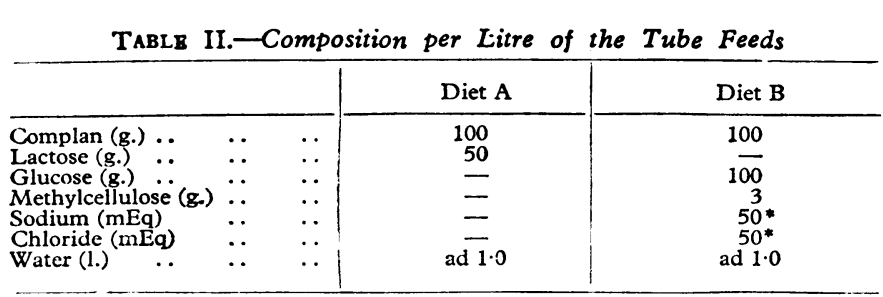

* Added to one of the three litres given per day.

TABLE III.-Daily Constituents of the Tube Feeds

\begin{tabular}{|c|c|c|c|}
\hline & & Diet A & Diet B \\
\hline $\begin{array}{ll}\text { Calories } & . \\
\text { Water (l.) } & \because \\
\text { Nitrogen (g.) } & \because \\
\text { Carbohydrate }(\mathrm{g} .) \\
\text { Fat (g.) } \\
\text { Protein (g.) } \quad \because \\
\text { Sodium (mEq) } \\
\text { Potassium (mEq) } \\
\text { Chloride (mEq) }\end{array}$ & 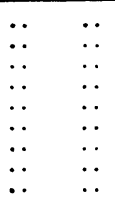 & $\begin{array}{c}1,950 \\
2 \cdot 56 \\
14 \cdot 4 \\
282 \\
48 \\
93 \\
66 \\
84 \\
60\end{array}$ & $\begin{array}{c}2,580 \\
2 \cdot 56 \\
14 \cdot 4 \\
432 \\
48 \\
93 \\
116 \\
84 \\
110\end{array}$ \\
\hline
\end{tabular}

Balance data were compiled on the basis of intake and urinary output, and corrections applied for losses from the lungs, skin, and stool, with added corrections for sweating and variations of blood urea. Patients with diarrhoea were excluded from analysis. The corrections applied for insensible losses are shown in Table I.

\footnotetext{
- Lecturer in Clinica! Pharmacology, University of Liverpool ; Medical Registrar, Intensive Care and Clinical Pharmacology Units, Whiston Hosp:tal, Prescot, Lancs.
}

The composition per litre of the two diets is given in Table II. Each diet was made up to 1 litre, and 3 litres of this was given per 24 hours in hourly aliquots of $125 \mathrm{ml}$. via a nasogastric tube. The constituents per 24 hours of these diets are shown in Table III. The method of preparing diet B has been described elsewhere (Jones and Peaston, 1966).

\section{Patients and Controls}

Seven healthy young adults aged 25 to 43 (four male, three female) received diet $A$, and subsequently seven further normal subjects aged 20 to 44 (five male, two female) received diet $B$. The modified diet $\mathrm{B}$ was then given to 20 patients aged 25 to 72 admitted to an intensive-care unit. Eleven of the patients had severe pulmonary infection, and 15 required I.P.P.V. for respiratory failure for a mean duration of 6.5 days. Thirteen of these cases required tracheostomy. The patients are tabulated in Table IV.

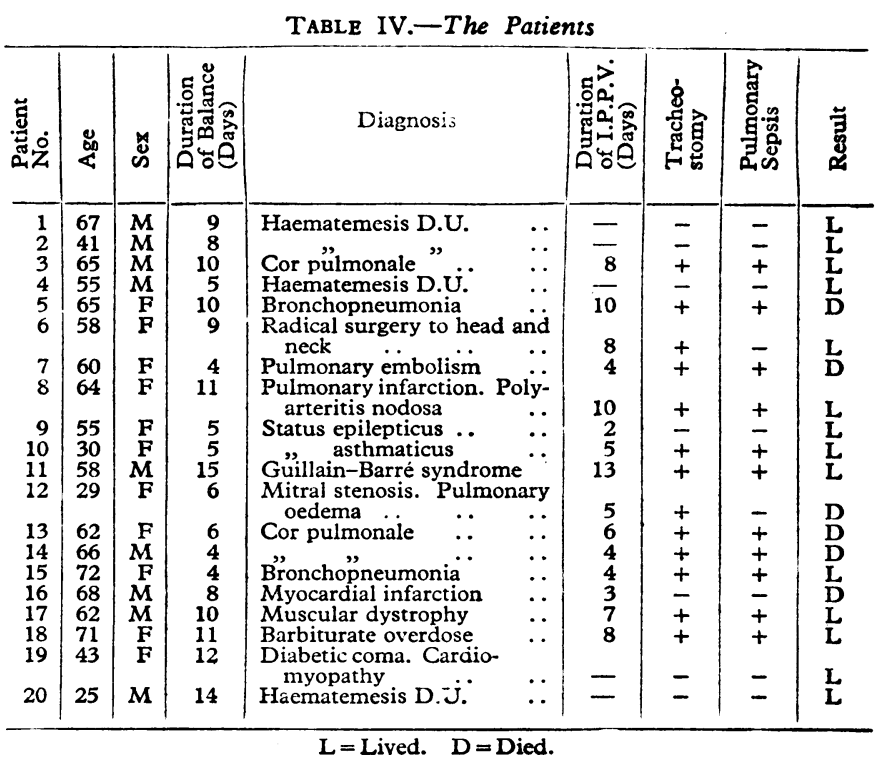

\section{Results}

On $\operatorname{diet} \mathrm{A}$ the seven controls showed an average weight loss of $0.87 \mathrm{lb}$. (395 g.) per day, and negative corrected balances for all the measured factors (Table $\mathrm{V}$ ). This was regarded as unsatisfactory, and the diarrhoea required early alteration of the tube feed. It was therefore modified to diet $B$, and in seven further controls the balance results showed a state of balance for sodium and potassium, with much smaller negative balances for water, chloride, and nitrogen. The negative balance for water was anticipated in controls leading normal active lives, and the small negative nitrogen balance indicated a much reduced loss of the lean muscle mass as compared with diet $A$. The average loss of weight was $0.05 \mathrm{lb}$. $(22.7 \mathrm{~g}$.) per day. In the patients, diet $B$ produced a satisfactory corrected 
balance for all factors, the negative balances for water and nitrogen being small.

\begin{tabular}{|c|c|c|c|c|c|c|}
\hline & \multirow{2}{*}{\multicolumn{2}{|c|}{$\begin{array}{c}\text { Diet A } \\
\text { Controls }\end{array}$}} & \multicolumn{4}{|c|}{ Diet B } \\
\hline & & & \multicolumn{2}{|c|}{ Controls } & \multicolumn{2}{|c|}{ Patients } \\
\hline $\begin{array}{l}\text { No. of subjects } \\
\text { Mean duration (days) }\end{array}$ & \multicolumn{2}{|c|}{$\begin{array}{l}7 \\
5 \cdot 0\end{array}$} & \multicolumn{2}{|c|}{$\begin{array}{l}7 \\
4 \cdot 6\end{array}$} & \multicolumn{2}{|c|}{$\begin{array}{l}20 \\
8 \cdot 3\end{array}$} \\
\hline & $\begin{array}{l}\text { Uncor- } \\
\text { rected }\end{array}$ & $\begin{array}{l}\text { Cor- } \\
\text { rected }\end{array}$ & $\begin{array}{l}\text { Uncor- } \\
\text { rected }\end{array}$ & $\begin{array}{l}\text { Cor- } \\
\text { rected }\end{array}$ & $\begin{array}{l}\text { Uncor- } \\
\text { rected }\end{array}$ & $\begin{array}{l}\text { Cor- } \\
\text { rected }\end{array}$ \\
\hline 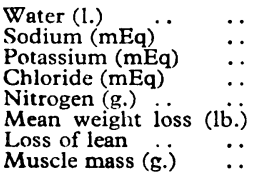 & $\begin{array}{r}0.4 \\
-17 \\
5 \\
-30 \\
-0.01\end{array}$ & $\begin{array}{c}-0 \cdot 6 \\
-27 \\
-7 \\
-38 \\
-2 \cdot 21 \\
0 \cdot 87 \\
66\end{array}$ & $\begin{array}{c}0 \cdot 79 \\
11 \\
18 \\
-9 \\
1 \cdot 07\end{array}$ & $\begin{array}{l}-0 \cdot 21 \\
1 \\
6 \\
-17 \\
-0 \cdot 53 \\
0 \cdot 05 \\
16\end{array}$ & $\begin{array}{c}1 \cdot 18 \\
66 \\
31 \\
51 \\
0.94\end{array}$ & $\begin{array}{l}-0 \cdot 477 \\
43 \\
16 \\
32 \\
-0 \cdot 15 \\
\\
13\end{array}$ \\
\hline
\end{tabular}

Of the patients analysed six died $(30 \%)$ as compared with a total annual mortality in the unit of 38 in $150(25 \%)$, and the mean duration of balance was 8.3 days, as compared with an overall duration in all patients admitted to the unit of six days. These figures indicate that the patients analysed represented a rather more severely ill group than the average of those admitted. Patients fed for shorter periods had less serious illnesses and were less likely to require prolonged ventilation, and the shorter duration of external balance made interpretation of data less informative. No patient presented here had balance data compiled for less than four days.

\section{Discussion}

The problem of diarrhoea with the original Complan-lactose diet required urgent resolution. Small laboratory animals whose liet is changed abruptly to one of low roughage content often develop severe intractable diarrhoea (G. A. J. Pitt, personal communication, 1964). Though increasing the osmolarity of tube feeds may produce diarrhoea (Masterton et al., 1963), that of the Complan-lactose diet was not high. Lactose intolerance in adults, however, is being increasingly recognized since the demonstration of absent or markedly reduced lactase activity in small-bowel biopsies from many patients with lactose-induced diarrhoea (Holzel et al., 1959 ; Auricchio et al., 1963 ; Dahlqvist et al., 1963). It has also been shown that a considerable number of normal adults are intolerant of lactose because of a deficiency of jejunal B-galactosidase from prolonged milk or lactose deprivation (Cuatrecasas et al., 1965). This has since been confirmed by others, who quote an incidence of about $35 \%$ (Haemmerli et al., 1965 ; McMichael et al., 1965) as compared with the $55 \%$ found by Cuatrecasas et al.

In this study, investigation into the precise cause of the diarrhoea was less important than the early design of a satisfactory diet from this complication. The modifications were therefore introduced together instead of in series, and the revised diet was used forthwith. With diet $\mathrm{B}$ the incidence of diarrhoea was less than $5 \%$.

In patients on diet $\mathrm{B}$ the small mean negative nitrogen balance indicated only trivial loss of the lean muscle mass, and the positive balances for sodium and chloride reflected adequate supplementation of the diet with electrolyte according to the predicted deficits on admission. The diet has proved clinically satisfactory in the management of some 250 patients admitted to an intensive-care unit.

\section{Summary}

External metabolic balance methods have confirmed that a tube feed of milk powder and glucose is able to maintain metabolic balance in patients with various serious illnesses admitted to an intensive-care unit. Corrected nitrogen balance showed only trivial loss of the lean muscle mass, in spite of the serious illnesses treated. The incidence of diarrhoea with a previous feed containing lactose was substantially reduced, and clinical observations confirmed that the diet was easy to organize, reduced the frequency of metabolic complications, and shortened convalescence.

The work was aided by grants from the Research Committee of the United Liverpool Hospitals, and the Polio and Cancer Research Club of Liverpool.

REFERENCES

Auricchio, S., Rubino, A., Landholt, M., Semenza, G., and Prader, A. (1963). Lancet, 2, 324.

Cuatrecasas, P., Lockwood, D. H., and Caldwell, J. R. (1965). Ibid., 1, 14. Dahlqvist, A., Hammond, J. B., Crane, R. K., Dunphy, J. V., and
Littman, A. (1963). Gastroenterology, 45, 488.

Haemmerli, U. P., Kistler, H., Ammann, R., Marthaler, T., Semenza, G., Auricchio, S., and Prader, A. (1965). Amer. F. Med., 38, 7.

Holzel, A., Schwarz, V.. and Sutcliffe, K. W. (1959). Lancet, 1, 1126. Hunter, J. (1837). The Works of fohn Hunter, edited by J. F. Palmer.

London.
Jones, E. S., and Peaston, M. J. T. (1966). Practitioner, 196, 271.

and Sechiari, G. (1963). Lancet, 2, 19.

McMichael, H. B., Webb, J., and Dawson, A. M. (1965). Ibid., 1, 717. Masterton, J. P., Dudley, H. A. F., and MacRae, S. (1963). Brit. med. f., $2,909$.

\section{Preliminary Communications}

\section{Ultrasound in Diagnosis of Liver Disease}

\author{
[With Special Plate]
}

\section{Brit. med. F., 1966, 2, 1368-1369}

Two-dimensional ultrasonography has been used in medical diagnosis for some years. The various visualization systems can be classified into two main groups. In one group the ultrasonic transducer moves in a water-bath, which provides the acoustic coupling with the patient. This is the method of Howry and Bliss (1952), Baum and Greenwood (1961), Gordon (1962), and Kossoff et al. (1964). In the other group the transducer is passed across the skin, which is coated with oil to ensure acoustic coupling. This method was developed by Donald and Brown (1961). Holmes et al. (1965) have described an apparatus similar to that of Donald and Brown. The present report is based on results obtained with a contact scanner, which, however, differs mechanically from the earlier systems. The scanning apparatus has been described elsewhere (Wells, 1965).

The echo information obtained during a scan is presented in the form of a brightness-modulated display on a cathoderay tube. The information is integrated photographically to provide a two-dimensional ultrasonogram.

The clinical results described in this article were all obtained with an ultrasonic frequency of $2.5 \mathrm{Mc} / \mathrm{s}$. Correction for tissue attenuation so that equal interfaces produce equal registrations, independent of depth, is especially important when scanning a relatively homogeneous organ such as the liver. This correction is applied by an electronic device which increases the sensitivity of the receiver with time, so that echoes which originate deep inside the patient are amplified more than those which are produced near the probe. For the examples presented here the sensitivity setting of the machine was kept constant. 